\title{
Wealth Destruction as a Sign of Iron Age Political Strife; the Greek Example
}

\author{
Kåre Fagerström
}

\begin{abstract}
In recent archaeological discussion it has become more or less accepted that grave-goods represent the destruction of wealth in order to enhance the personal prestige of the person who makes the offerings. This is accomplished through (a) the prestige of the ancestor buried which is transferred upon the individual who arranges the funeral, (b) through the prestige the individual gains from the funeral feast itself. This presupposition is contrasted against the sacred place offerings, which are seen as the offerings of a community-even if the community is represented by an individual-at either local or "international" sanctuaries. Offerings at local sanctuaries are seen as indications of a more stable hierarchy, where the leaders can gather the whole community without any problem. Offerings at the international sanctuaries are seen as indications of communities so stable as to be able to send representatives to the international gatherings. Such offerings enhance the prestige of both the individuals and the communities represented. The essay ends with an outline of the Greek Iron Age with a brief discussion on how the hypotheses presented fit the evidence as it can be read.
\end{abstract}

Kåre Fagerström, Skarpbrunnavägen 33, S-145 65 Norsborg, Sweden.

The following essay is intended as a preliminary to a major work I hope to be able to do on the material remains of the symbolical expressions of different groups and individuals competing for power in an Iron Age context. For that study I have chosen the Argolid as a case area, mainly because this area combines the advantages of being relatively well excavated and surveyed with enough ancient renown to figure rather prominently in the literary sources of the period. Here, however, I have chosen a more general approach, as much of the detail work on the Argolid remains to be done. I therefore submit this essay to discussion in order to test the ideas that have provoked me to look further into the matter of symbolical expression and internal tension.

\section{THE HYPOTHESIS}

A number of recent studies note that there are signs of a negative reciprocal interplay between grave-goods and communal offerings in societies where the ostentatious destruction or discarding of wealth plays an important part in the ritual (e.g. Randsborg 1989:49;
Morris 1987:23; Collis 1989 [1984]:78; Snodgrass 1989:30; Bradley 1984:20-25 and passim). Usually this notice is not commented upon, but an attempt is made by Klavs Randsborg to explain the phenomenon as it appears in Denmark, with regard to climatological factors which affected the subsistence (Randsborg 1989:49). While there is no doubt a lot to be said for this argument, it is doubtful whether it is a true explanation. Climatological and other environmental factors arguably do not directly affect human society, only indirectly, in the sense that the prerequisites for living are changed. Other factors could be instrumental in producing similar results, and environmental factors are quite elusive in their visible effects. That is to say that most negative changes in the environment tend to produce stress in varying degrees, which in itself produces dramatic changes in the social relations between the members of a community. But social changes of a superficially similar kind can be produced by other than strictly environmental changes, like changes of subsistence production for social or developmental reasons, changes in other areas of the 
economy, etc. In other words, what we see is the impact of social change on the surviving expressions of culture, regardless of the causes behind that change. (cf. Collis 1989 [1984]:78). For this reason I believe it to be more promising to try to separate the social factors which directly triggered the change, than to postulate a more remote and less readily discernible climatological factor, at least in the first round of enquiry (cf. Hodder 1984).

\section{GRAVE-GOODS}

The observations of reciprocal interplay between grave-goods and communal offerings suggest that these forms of ritual may have been to some degree mutually exclusive, which is an indication of a causal relationship between them, and it may therefore be rewarding to look into that problem. To take as a starting point the Iron Age of Greece is not only a personal bias of my own, but the period also presents a fairly well known field of inquiry, especially where graves are concerned.

Starting with the graves, it is more or less customary to set aside a section for the social implications of the burial. For the Attic material, this is done in a study by Ian Morris (1987) and all that is needed here is a brief summary of that material later to be complemented with a more profound look into the Argive material. Here the main source of information consists of the works of Courbin and Hägg, along with a number of excavation reports (Courbin 1966; 1974; Hägg 1974; 1980 : 119-126). For the time being, however, it is sufficient to treat the mainland of Greece as an entity in this case, saving the specialised reports for future work.

A funeral can be split up in ritual terms into a rite of separation and one of aggregation encasing a marginal state. The marginal state with its transitorial rites is preceded and succeeded by "normal" states, and the participants are the mourners, the corpse and soul of the deceased (Morris 1987:30-31). The ritual is normally seen as an attempt to make peace with the chaotic, disruptive forces of death which threaten the entire society and the mourners in particular; the latter passing through a period of pollution.

Such information is of course vital for our understanding of funerary practices, but its practical value for archaeological purposes is perhaps less clear. Information we have from various sources suggests that the funerary rites also presented an opportunity for ostentatious neutralisation of wealth (Cf. e.g. Il. 23; Popham, Touloupa \& Sackett 1982:169-174). Without trying to diminish the amount of true grief felt by the mourners (e.g. Od. xi.59-78), one can hardly deny that the destruction and discarding - neutralisation, in other words of vast quantities of valuable goods is a show put on more for the living than for the dead (e.g. $I l$.VII. $81-91$, where the funerary monument of his slain enemy is taken to enhance Hector's glory). The magnificence of the show, however, is determined by the social persona of the deceased. Just as this persona governed the degree of separation from the community during mourning, so it also determined the scale of the funerary ritual (Morris 1987:110 ff). As also noted by Morris, the funerary legislation by Solon recognises the rituals as demonstrations of power and influence (Morris 1987:50).

The most original form of wealth neutralisation is possibly the competitive gift-giving in redistributive societies (Mauss 1969; Qviller 1981:109-155; Finley 1979). The distribution of gifts between heads of societies and the redistribution of goods among their subjects carried with them great prestige. In the Mycenaean societies the wanax acted as the redistributor in what seems to have been a strictly formalised society. The wanax was like the hub in a redistributive wheel. The removal of the wanax would have had the same effect as the substitution of Oinomaos' mythical and proverbial linch-pin for one of wax: the entire construction crashed to the ground. Hence the Iron Age Greeks had to build their own societies virtually from afresh (Fagerström 1988a:139-145). Elaborate funerary ritual involves the neutralisation of sur- 
plus goods which at least in part were offered to the gods and the dead, and hence served no immediately practical purpose. No doubt there were spiritual overtones in the ritual, but it can hardly be doubted that the magnificent festivals in connection with the funerals also served to enhance the prestige of the survivors. Those who benefitted from the neutralisation of wealth were those who provided the show - the deceased's family. Regarded thus, funerary rites provided an occasion for the enhancement of personal prestige, founded on a family or kinship basis. Thus one of the laws of Solon, constructed in order to quench the social unrest of his times, was the limitation of funerary expenses and other excesses (Cicero, De legibus 2. 26. 64-66).

Hence it is apparent that funerary rites are important in the establishment of social status in primitive societies, but this is not the sole aspect of funerals. Grave-goods play an equally important, if slightly different role. They are on display at the very funeral, but afterwards they survive, hidden underground, albeit doubtlessly remembered. Grave markers form yet another category, this time not necessarily erected at the very funeral, but designed to form an eternal marker of the magnificence of the one entombed and shedding equally eternal glory upon his survivors (Cf. I/.VII, 8191).

We thus have three symbolical categories in a funeral: (1) wealth destroyed on the spot to glorify the ceremony, (2) wealth destroyed and hidden to serve as a mental memorial of the magnificence of the entombed, and (3) the grave marker, serving as the visible memorial of this same magnificence. A problem arises at the next level, the very ritual. This may be seen as designed to implant the memory of the dead persona in the collective memory of the community. If so, it should perhaps be regarded as a medium rather than a monument.

\section{SACRED PLACE OFFERINGS}

Turning to offerings in sacred places - groves, rivers, lakes, bogs, or sanctuaries - these are not merely reflections of societal piety, but also an opportunity for the display of communal or group prestige. This can take on a variety of aspects, from that of entire societies displaying their wealth and demonstrating their prowess through offerings in "international" sanctuaries, to the demonstration of one group of its superiority in terms of wealth and magnificence over other groups in the same society in "national" or local sanctuaries. The difference of message is articulated in the scope of the sanctuary. The difference between sacred place sacrifice and funerary ritual is then that the sacred place sacrifice emphasises groups of people which need not share a family or kinship relationship, while the funerary ritual emphasises precisely that particular kind of relationship; along with the individual who is organizing the funeral.

This reasoning does not exclude private offerings at sacred places, but sees these as given by individuals in their role as members of - even spokesmen for - a community. The offerings at local sanctuaries are then carried out in order to enhance the local prestige of the individual, so he can gain or maintain a position as head of the community. On the "international" level, at the great Panhellenic sanctuaries, for instance, the same individual is making offerings in his own name as a representative of a community. The community then shares the glory bestowed upon the resourceful individual, whereby the offering works both ways: it strengthens the individual's local prestige and enhances the wider prestige of the community. The appearance of the Panhellenic sanctuaries thus paved the way for institutionalised power, as it would be very hard for a community to denounce its gratitude to such a pious and righteous man as one who makes great offerings at the great sanctuaries. In this context it would be gratifying to establish a competition between Sparta and Argos in the offerings at Olympia, coinciding with their alleged conflict in the eighth century, but it is doubtful whether a stylistic analysis would be a precise enough tool to do the job. Anyway, the Olympic peace may well 
have been instituted partly as a reaction to physical action following upon the symbolical competition in offerings. The first known breach of the Olympic truce was that of Phaidon of Argos in 676 or 668 (Jeffery 1978:136,168).

As regards the three symbolical categories, these are still visible in sacred place offerings. Ritual is less easily discernible archaeologically than the others, but its occurrence can usually be taken for granted. The hidden items corresponding with the gravegoods can be seen in bog offerings and also in the sacred burial of older offerings in bothroi in order to make way for new ones. The visible communal offerings are rather obvious, the pride of place being taken by the very temple. The temple, interestingly, seems to represent the manifestation of the tyrant Kypselos, as the excavations at Ancient Corinth and Isthmia have yielded nothing earlier than c. 625 , a time which beautifully fits the period from Kypselid overthrow to the death of Periander (657-c.585) (Cf. Jeffery 1978:146-148). Also, the establishment of the Heraion at Argos can be taken to coincide in time with the rather elusive figure of Phaidon, or at least one unification of Argos as a national entity (Waldstein 1902; Wright 1982; Jeffery 1978:134-136). The earliest Greek temple now appears to have been the Heraion at Samos, but its alleged 9th century date must be seriously doubted (cf. Fagerström 1988a:8586).

These two kinds of emphasis - private and public - are more or less mutually exclusive, because larger groups cannot tolerate that individuals belonging to any one privileged family rise above those of the rest of the leading group of families. If this should after all occur, the group is no longer a dominating group, but a dominated one (cf. e.g. Jeffery 1978:145). Now it becomes apparent why the two kinds of wealth neutralisation strategies can be termed private or familial and communal or group wealth neutralisation strategies, and why they reflect two different - indeed mutually exclusive - ways of wielding power or brandishing prestige. Excessive offerings in graves and grave monuments are the material remains of a power structure based on kinship or private prestige, while excessive sacred place offerings reflect a power structure based on larger groups of not necessarily genetically related people. As the material remains constitute the archaeological evidence, it follows that offerings of these kinds are the archaeological records of two different kinds of power structures.

\section{SYMBOLS, ECONOMY, AND POLITICS}

One problem remains, however, and that is the definition of the term excessive. It must be admitted that where definitive evidence for either wealth neutralisation strategy fails to prevail, this does not necessarily signify an egalitarian society, as there are other ways of establishing prestige than by the neutralisation of wealth. It is also possible that what we see as fairly poor graves may well have been regarded as rich. The Submycenaean period is a case in point. The graves are usually accepted as being "generally poor" (Morris 1987:18), but poor in relation to what? Evidently they are poor in relation to the previous Mycenaean and the subsequent Protogeometric and later graves. But it is equally commonly accepted that the Submycenaean period was one of general material poverty, at least in goods durable enough to have been preserved. The pottery of the period is also rather often looked down upon by scholars. Still, the wealth or poverty of the graves must reasonably be judged against the general wealth of the period, and especially against the wealth - or the lack of it - of the sacred place offerings of the period (Snodgrass 1980:53,105). I have in another context argued that the Early Iron Age in Greece was a society of a primitive herding economy, governed by "big men" or chieftains - basileis - in a rather loosely knit society (Fagerström 1988a:139-144; 1988 b:33-50 and see Rapp, G. \& Aschenbrenner 1978:74, and McDonald \& Coulson 1983:323). The basileus' power was built largely on per- 
sonal prestige, and it is quite likely that his survivors used part of his collected wealth in order to build on his personal prestige and claim part of it for themselves, whether as heirloom or the ostentatious neutralisation of it as offerings. This might then have initiated a process which ought to be traceable in the archaeological record until the crises occurred which transformed the rule of these very locally based basileis and turned the Early Greek society into what it emerges in history as; most commonly an aristocracy.

The persistence of ritual noted by Morris (1987:50), where vase grave markers were used for centuries and with similar scenes of mourners, lying-in-state and processions from Late Geometric to Red Figure, is another indication that the spiritual essence remained unchanged in the Iron Age. If the spiritual contents remained the same, something else must have provoked the great changes in burial practices during the Iron Age, and it seems to me that a claim can be made for the case of social prestige, which would demand both a great emphasis on wealth and on originality.

There is a danger of over-simplification in this line of thought. Morris notes that the sixth-century funerary monuments reached a peak in the third quarter of the century, while they get simpler in Early Red Figure. This decline would coincide with the Peisitratid coup $d$ etat, an occasion which certainly emphasised one single family. In this period, however, we are dealing with a much more complex society, and the Peisistratid coup meant that power was centralised. The preceding period, the second half of the seventh century and the first three quarters of the sixth, had been characterised by an ever-increasing emphasis on grave markers, a phenomenon which ought to imply a struggle for influence among a number of aristocratic families, culminating in the Peisistratid take-over. This development is supported by a number of historical hints and references (Jeffery 1978:8394), and the reasons for the struggle were swept away by Peisistratos. With the introduction of democracy it became meaningful to raise grand mortuary monuments again in order to enhance personal prestige, while at the same time communal self-consciousness was also being promoted, in Attica it seems that the growing democracy placed strict rules on the expenditures on grave monuments (Morris 1987:205-208).

We thus find aspects of strife and social conflict in this topic, too, and that the mutual exclusiveness of the two kinds of wealth neutralisation strategies was not absolute. The general principle remains unaffected, though; what this added aspect does is to demand a thorough scrutiny of the evidence along with a far-reaching analysis of the interplay between sacred place and grave offerings. Analyses of burial customs can, as Bradley's and Morris' (Bradley 1984; Morris 1987) brilliant studies have shown, reach far into the societal nature of a prehistoric community, but there may be an added dimension if the sacred place offerings are permitted to enter the analysis as indicators of social unity and internal stability as opposed to the internal instability and social upheavals which are heralded by an undue emphasis on offerings in and elaboration of tombs, signifying struggle for private prestige on a family basis. Seen thus, each of the two wealth neutralisation strategies becomes the counter-image of the other.

The table of offerings at sanctuaries compiled by Snodgrass, speaks clearly in favour of an 8th century boom in offerings at the greater sanctuaries (Snodgrass 1980:53). Snodgrass notes that there is a drop in the number of grave-goods in Greek burials, although the rise of the votives occurs earlier in the 8 th century than the decline in grave-goods.

The statement calls for some comment. First it suggests that the rise of sanctuary material and fall of grave-goods respectively, occurred more suddenly than one would have expected. It seems more likely that the process should have been a gradual one, and much of the chronological difference would be removed by a gentler bending of the imaginary curves, assuming the apparent suddenness to have been caused largely by archaeological 
dating habits, where chronological flexibility is traditionally disregarded. Secondly, what remains of the implied chronological discrepancy after such an operation is merely natural, as it should be expected that a new behavioural principle has to be established before it can oust an old one; at least to the extent that the ousting is archaeologically discernible.

A pastoral economy, I have argued, is more inclined to manifest itself through conspicuous consumption than an agrarian one, which manifests itself more properly through conspicuous storage (Fagerström 1988a:144145). Translated into terms of ritual, conspicuous consumption can be seen as reflected in elaborate funerals, both being of a "here-and -now" type of character, while conspicuous storage is better reflected in sacred place offerings, being of a more permanent kind. The difference in kind can also be expressed thus: conspicuous consumption and funerary ritual are of an active and temporary character, while votive offerings and conspicuous storage are the manifestations of an ideal of dormant but permanent wealth. The rise in sanctuary votives would thus reflect an agrarian society, while the grave-offerings would reflect the earlier Iron Age pastoral interlude. Such a conclusion cannot be used directly as an hypothesis, it has to be tested and correlated with other evidence for the change in subsistence strategies. It also has to be augmented by the evidence for increased political and social complexity as argued above, but perhaps it is pertinent to build a tentative chronological model of these changes at this stage.

First of all, it must be emphasised that there was no immediate, total, and wholesale revolution. The changes appeared gradually or one at a time, and were adopted with different intervals and individual selection at different places. A reversion to an agrarian economy is not immediately followed by the societal changes indicated above, but only after a period of time, when the effects of the initial change are beginning to be felt. The change in economy is in itself likely to be the effect of a rise in population, the mechanisms behind which are not yet fully understood. An agrarian economy is in itself capable of sustaining a larger population than a pastoral one is, and it also introduces new means of manifesting wealth and prestige, most importantly what I have termed conspicuous storage. The change from grave- to sacred place offerings as the major display of wealth springs less readily to mind, especially to those concerned, and may be one of the last of the new introductions. Still, once it is realised, its impact ought to have been enormous, and its relation to the locally fixed agrarian economy must have been realised too - at least at an unconscious level. Characteristically, private individuals were not late in discovering the potential involved in posing as representatives of the entire population at public offerings.

As the population grew and contact between two or more privately owned pieces of land became increasingly common, not only was the manifestation of private wealth increasing, but finally the need for a new and independent societal body to govern the competing farmers made itself felt. That this body eventually took the form of the polis in many Greek states is a highly complicated topic, but by then, at least, the outcome is known.

\section{CHRONOLOGICAL SUMMARY WITH CONCLUSIONS}

The Submycenaean and Protogeometric periods are characterised by a material from the sanctuaries which is very scant indeed. Thus we should expect the graves to be rich, but this seems at first sight not to be the case. Using the example of Attica, the graves are considered to have been "generally poor" during Submycenaean, and "fairly consistently poor" during Protogeometric, although an increase is noted towards the end of the period (Morris 1987:18-19). There may be reasons to be cautious about this apparent poverty, however, since there is no certain variable against which one can relate it. It would seem, in fact as if the amount of grave-goods in Submycenaean and Protogeometric tombs would com- 
pare fairly favourably with other sources of material from the same time.

After the fall of the Mycenaean palaces, there must have been a period of near-anarchy, at least in the sense that Greece of that time was so scarcely populated that institutionalised government was not really necessary. This presupposes that the depopulation of Greece was as great as usually assumed. Quite incidentally, this argument also supports the relative historicity of certain myths, like that of the adventures of Theseus while walking from Troizen to Attica. Such exploits are conceivably set in the mystery surrounding a depopulated scenery, but hardly in the overexploited countryside of Archaic times. In this depopulated Greece, unrestrained by any formal government, the surviving population took up the easiest form of subsistence they knew; primitive herding with some additional small-scale farming, as it appears mainly of legumes and similar garden-plants rather than field-crops like cereals.

The Submycenaean is often described as a period of severe poverty, drabness and loneliness, almost to the extent of producing a mental picture of certain post-nuclear-war predictions. But one can just as well construct the opposite scenario of a leisurely life where the necessary tasks were reduced to a small backyard vegetable lot, the occasional (not necessarily even daily) slaughtering and roasting of an animal, or the construction of a house from the simplest materials imaginable. Although neither of these pictures is likely to be quite true, I am personally inclined to favour the latter, perhaps mainly because it appears as if the Greeks of the period actually did revert to a primitive herding economy (Cf. Snodgrass 1980:20).

Such simple societies may well lack formal government, but they usually have an informal subsitute: personal prestige. Such prestige may carry with it an element of heredity, although this is not necessary (Qviller 1981:117-118).

The Early and Middle Geometric Periods. This is the time in which I assume the "reagriculturation" of Greece begins. There is some evidence for an economy based more on arable farming towards the end of the "Dark Age" at Messenia from MG and onwards, the Attic granary models begin to appear in the period, and the possible granary bases at Lefkandi are also from this time, linked to a house of SPG date. Similarly, the first complex houses and store rooms also appear in MG, at Asine, and Zagora, for example (Fagerström 1988a:133-139).

The first part of the period probably lacked formal centralised government as well, but the land was beginning to become a commodity which one could own, and hence it became more obviously hereditary. This is the period in which the aristocracy begins to separate itself as a more clearly defined group, if not yet quite reaching the status of a landed gentry.

Some form of national unity ought to have been experienced, as the first signs of copious offerings appear at Olympia, at first as figures of warriors or of Zeus, later as cauldrons, and later still as pieces of armory. This is an interesting sequence, as the figurines of warlike character are succeeded by the cauldrons, which are more of wealth-indicators, and these in turn are followed by actual helmets, greaves and breast-plates (see Snodgrass 1980:105 and Mallwitz \& Hermann 1980). The change must be significant: in Homer cauldrons typically are gift objects or prices, profits from peaceful competition.

The Late Geometric Period and after. The late Geometric period is one of a rising amount of offerings at the panhellenic sanctuaries, and of decreasing amount and value of the grave-goods. In Athens graves are frequently marked by large vases, a practice which may seem a bit ambiguous from the point of view presented here. The vases must mean some special kind of distinction, and apparently a rather new emphasis on the tomb as an "eternal' monument, as opposed to the emphasis on the transference of prestige from the dead to the living as expressed by elaborate funerary feasts ("the basileus is dead, long live the 
basileus"). At the same time it is possible to argue that the new practice is an economisation of funerary ritual, in concordance with the agrarian preoccupation with storage. The persona of the dead is leaving the community of the living much more quietly than by means of funerary festivities, but his/her spirit is immortalised, not only by his kleos (glory, honour), but also by the monument (e.g. Nagy 1981:28). The implications are complex, but if one should try to summarise, agrarian communities headed by a fairly stable proto-aristocracy based on arable farming seem to be what we have at hand. The change to more war-like offerings at Olympia towards the end of the period may indicate troubled times, coinciding, incidentally, with the obscure references to wars between Athens and Megara (Jeffery 1978:83-84), the Lelantine War (Wright 1982:186-201) and the first Messenian War (Jeffery 1978:114-117). There is nothing even remotely resembling solid evidence that any of these wars ever took place, but if they did, this period provides us with a setting more likely than that of any other period. We have a period of agrarian protoaristocracy, of a population increase, which had probably reached the limits of the technology available at the time, and the societal complexity which makes the conflicts between the states involved likely; typically that of the Lelantine Plain fought over by Chalkis and Eretria.

At the same time, roughly in the LG period, Hero-cults appear (Coldstream 1975-76; Antonaccio 1987; Morris 1988; Whitley 1988; Alcock 1991). The first signs of an early floruit of this peculiar kind of cult fall within this period and appear in some of the more prominent areas of the period, such as Argolis, Attica and Euboea. The simultaneous appearance in Attica and Argolis is interesting, as these two areas differ somewhat in other respects. The Hero-cults can be seen as the conspicuous ritual establishment of the prestige of dominating families, alluding to alleged and claimed pedigrees.

Concerning the relationship between the
Hero-cults and the Homeric poems, it seems clear that, by and large, they all belong to the same general period, the Late Geometric (Coldstream 1975-76:9; Janko 1982). For this reason it seems likely that the working hypothesis ought to be that they represent two sides of the same thing. The hero is a highly important figure in Iron Age Greece, and in the Homeric poems he is already beginning to take on an international aspect. Thus the Iliad is not about Achilles, it is not about Agamemnon it is about the Achaeans, the Greeks. Achilles is the main figure, true, but he is the shield of the Achaeans, his glory is theirs, etc. He thus represents the Achaeans in precisely the same way as the offering gentlemen at e.g. Olympia represented their native poleis and together the "confederation" of Helladic poleis. Similarly, the Odyssey is about the formation of the Ithacan ethnos, since it tells us about the power struggle between competing groups of aristocrats - even though in a somewhat allegorical way.

The Hero-cults at e.g., the Argive Heraion probably reflect the formation of the Argive polis on a similar scale of concept (Waldstein 1902; Wright 1982). My approach to the Herocults is thus coloured by this similarity with the Homeric songs, although I do not believe, as has been suggested, that the songs originated the cults. It seems much more likely that the cults and the songs are parallel outputs of the same general feeling, very much in the same way as myth is related to rite.

\section{FINAL NOTE}

Archaeology is generalisation. We can never reach the particular, which is the hallmark of history. Still, working with indications and hints from the material remains is not necessarily inferior to working with discrete utterances from once living beings - it certainly is as intellectually intriguing - and we should allow the indicators to work together whenever they can. I have here proposed a pair of opposites - the private tomb versus the public offering - together with a suggestion of how 
to interpret this pair in political terms. It seems to me that the pair of opposites suggested opens a little gap in the wall of anonymity of Iron Age Greece. If this approach could be augmented by refined arguments from other angles, it would certainly carry us a long way towards a deeper understanding of the period.

\section{REFERENCES}

Alcock, S. E. 1991. Tomb Cult and the Post-Classical Polis. American Joumal of Archaeology 95: 44760.

Antonaccio. C.M. 1987. The Archaeology of Early Greek Hero Cult. (Diss. Princeton Univ.).

Bradley, R. 1984. The Social Foundations of Prehistoric Britain - Themes and Variations in the Archaeslogy of Power (Longman Archaeology Series) London \& New York.

Coldstream, J.N. 1975-76. Hero-Cults in the Age of Homer. Joumal of Hellenic Studies 95-96:8-17.

Collis, J. 1980. The European Iron Age. London.

Courbin, P. 1966. La céramique géometrique de l'Argolide (Bibliotheque des Écoles françaises d'Athenes et de Rome, fasc. 208). Paris.

- 1974: Tombes géometriques d'Argos. Vol. I. 19521958 (Études péloponnésiennes, 7). Paris.

Fagerström, K. 1988a. Greek Iron Age Architecture Developments through Changing Times (Studies in Mediterranean Archaeology LXXXI). Göteborg.

- 1988 b. Finds, Function, and Plan, a Contribution to the Interpretation of Iron Age Nichoria in Messenia. Opuscula Atheniensia 17:3.3-50.

Finley, M.I. 1979. The World of Odyseas. Harmondsworth.

Hägg. R. 1974. Die Gräberder Argolis in submyenischer. protogeometrischer and geometrischer Zeit $\mathrm{I}$. Uppsala.

- Some Aspects of the Burial Customs in the Argolid in the Dark Ages. Athens Annals of Archaeology 13:119-26

Hodder, I. 1984. Reading the Past: Carrent Approaches to Interpretation in Archaeology. Cambridge.

Janko, R. 1982. Homer, Hesiod and the Hymns: Diadhonic: Developments in Epic Diction (Cambridge Classical Studies). Cambridge.

Jeffery, L.H. 1978 (1976). Archaic Greece; the CityStates c. 700-500 B.C. London \& Tonbridge.

McDonald, W.E. \& Coulson, W.D.E. 1983. Excatations at Nichoria in Souhwest Greece. I1]. Dark Age and Byzantine Occupation. Minneapolis.
Mallwitz, A. \& Hermann. H.-V.1980 (eds.). Die Funde aus Olympia, Ergebnisse hundertjähriger Ausgrabungs-fähigkeit (Deutsche Archäologische Institut). Athens.

Mauss, M. 1969. The Gift. Fom and Function of Exchange in Archaic Societs. London.

Morris, 1. 1987. Burial and Ancient Society-the Rise of the Greek City-State. Cambridge.

- 1988. Tomb Cult and the 'Greek Renaissance': The Past in the Present in the 8 th Century B.C. Antiquity 62:750-61.

Nagy, G. 1981 (1979). The Best of the Achaeans Concepts of the Hero in Greek Poetry. Baltimore \& London.

Popham, M.R.. Touloupa, R. \& Sackett, L.H. 1982. The Hero of Lefkandi. Antiquity 56: 169-174.

Qviller. B. 1981. The Dynamics of the Homeric Society. Symbolae Osloensis 51:109-155.

Randsborg. K. 1989 (1984). The Viking Age in Denmark - the Formation of a State. London.

Rapp, G. \& Aschenbrenner, S.E. 1978. Excavations at Nichoria in Southwest Greece. I, Site, Environs and Techniques. Minneapolis.

Snodgrass, A.M. 1980. Archaic Greece, the Age of Experiment. Berkely \& Los Angeles.

- 1989. The Coming of the Age of Iron: Europe's Earliest Bronze/lron Transition. In: Marie Louise Stig Sorensen \& Roger Thomas (eds.), The Bronze Age - Iron Age Transition in Europe; Aspects of Continuity and Change in European Societies $c$. 1200-500 B.C. (British Archacological Reports: International Series 483):22-35.

Waldstein, C. 1902. The Argive Heraeum. Vol. I, General Introduction, Archilecture, Marble Statuary, and Inscriptions. Boston \& New York.

Whilley, J. 1988. Early States and Hero Cults: A Reappraisal. Journal of Hellenic Studies 108:173-82.

Wright, J.C. 1982. The Temple Terrace of the Argive Heraeum and the Cult of Hera in the Argolid. Joumal of Hellenic Studies 102:186-201. 
